\title{
FAKTOR DOMINAN PENGARUH BAURAN PROMOSI TERHADAP PRILAKU KOSUMEN DALAM KEPUTUSAN PEMBELIAN SUATU PRODUK
}

\author{
Luna Theresia Tambunan \\ Sekolah Tinggi Ilmu Ekonomi LMII, Medan \\ Jl. Kolam No.41 Medan \\ E-mail: luna88tambunan@gmail.com \\ diterima: 1/2/2019; direvisi: 4/2/2019; diterbitkan: 31/3/2019
}

\begin{abstract}
This study aims to determine the mix of dominant factors and promotional indicators that influence consumer behavior towards purchasing decisions of a product. The sample of this study was 105 people $(n=105)$, STIE LMII students, Medan 2018-2019 academic year. The research instrument used a questionnaire. Data analysis uses path analysis with structural equation models. Based on the results of data analysis, it can be concluded that simultaneous promotional mix, namely publicity and sales promotion, and partially, namely publicity, sales promos, and direct marketing are dominant factors that influence consumer behavior in making handpone purchasing decisions. Based on sales promotion indicators, namely (1) directing consumers' attention to products, (2) encouraging prospective customers to buy, and (3) arousing the desires of prospective consumers to make purchases, as well as factors of publicity, namely actual reporting consumer behavior in making purchasing decisions for a product.
\end{abstract}

Keywords: Promotion mix, consumer behavior, purchasing decisions

\section{PENDAHULUAN}

Pemasaran satu bagian penting dalam mendistribusikan suatu produk kepada konsumen. Pemasaran adalah suatu kegiatan yang ditujukan untuk merencana-kan, mempromosikan, dan mendistribusi-kan barang dan jasa yang dapat memuaskan kebutuhan pembeli (Swastha \&Tani, 2000). Menurut Hasan (2008) bahwa pemasaran merupakan suatu strategi bisnis yang bertujuan untuk mencapai keputusan berkelanjutan bagi stakeholder. Strategi pemasaran adalah proses perencanaan dan implementasi kebijakan perusahaan untuk mewujudkan tujuan-tujuan perusahaan (Hermawan, 2012). Sedangkan bauran pemasaran dapat digunakan oleh pengusaha untuk mempengaruhi konsumennya dengan melakukan tindakan-tindakan pada produk, harga, promosi dan distribusi (Gitosudarmo, 2000).

Promosi unsur penting dalam strategi pemasaran yang dapat mempengaruhi peningkatan volume penjualan. Promosi adalah salah satu variabel pemasaran, aktivitas pemasaran, dan jenis komunikasi untuk meyakinkan calon konsumen tentang barang dan jasa dalam rangka meningkat-kan permintaan oleh konsumen (Stanton, 1991; Alma, 2005; Sunyoto, 2013; Hermawan, 2012; Tjiptono, 2001; Babin, 2011). Bauran promosi terdiri atas lima unsur, yaitu advertising, personal selling, publicity, sales promotion dan direct marketing (Kotler, 2005). Hasil penelitian menunjukkan bahwa bauran promosi berpengaruh positif dan signifikan terhadap keputusan pembelian (Wariki, Mananeke \& Tawas, 2015). Oleh karena itu perlu diketahui faktor paling dominan untuk dapat digunakan sebagai pertimbangan dalam pelaksanaan pemasaran suatu produk.

Manakah faktor dominan unsur bauran promosi yang mempengaruhi perilaku konsumen terhadap keputusan pembelian suatu produk handpone? 
Jurnal Ilmiah Ekonomi dan Bísnis

Vol. 16. No.1, Maret 2019: 35-45

EISSN : $2442-9813$

ISSN : $1829-9822$

Manakah faktor dominan indikator dari bauran promosi yang mempengaruhi perilaku konsumen terhadap keputusan pembelian suatu produk handpone?

\section{TINJAUAN PUSTAKA}

Advertising (periklanan) salah satu media yang digunakan oleh perusahaan untuk memperkenalkan produk. Iklan adalah bentuk komunikasi yang menggunakan media untuk menjangkau audiensi yang luas dalam rangka memberikan informasi tentang suatu produk (Moriarty, 2009). Iklan adalah promosi ide melalui beberapa media (Kotler \& Keller, 2012). Iklan dapat mempengaruhi prilaku konsumen, hal itu dapat dilihat dari beberapa hasil studi. Hasil penelitian Surjadi (2012) menunjukkan bahwa ada pengaruh iklan terhadap perilaku konsumen. Penelitian lain menunjukkan bahwa iklan berpengaruh terhadap sikap, dan minat konsumen (Qolbi, Fauzi \& Sunarti, 2014; Yuniyanto \& Sirine, 2018). Iklan dapat diukur dengan beberapa indikator, yaitu (1) menarik perhatian, (2) memiliki daya tarik, (3) membangkitkan keinginan berbelanja, (4) mendorong untuk melakukan pembelian (Tjiptono 2008).

Personal selling (tenaga penjual) adalah penyampaian yang dilakukan oleh seorang sales secara lisan dan langsung untuk menjual suatu produk kepada calon konsumen (Kotler, 2007). Penggunaan personal selling memberikan dampak terhadap penjualan produk. Hal tersebut dapat dilihat dari beberapa hasil penelitian yang menunjukkan bahwa personal selling berpengaruh positif terhadap keputusan pembelian (Fortunisa \& Agassi, 2012), pengaruh yang siginfikan terhadap intensi membeli yang dilakukan oleh konsumen (Yudhiartika \& Haryanto, 2012). dapat menarik minat calon konsumen (Dellamita, 2014), mempengaruhi keputusan pembelian (Panjaitan, 2016; Kusmayani, 2014), dan ada hubungan personal selling dengan keputusan pembelian (Yunita, 2013, Priyanto, 2014). Personal selling dapat diukur dengan tiga indikator, yaitu (1) interaksi pribadi, mencakup hubungan langsung dan interaktif antara dua orang atau lebih, (2) perkembangan hubungan, meliputi hubungan yang berkembang mulai dari hubungan penjual sampai hubungan yang lebih baik dengan konsumen, dan (3) tanggapan, yaitu personal selling membuat pembeli lebih mendengarkan pembicaraan penjualan (Chandra, 2016).

Publicity (publisitas) merupakan upaya promosi yang digunakan dalam bentuk media tulisan atau tanyangan visual untuk menarik perhatian konsumen dalam mencapai tujuan pembelian. Publisitas adalah sejumlah informasi, penyebaran ide, dan suatu komunikasi dalam bentuk media untuk memperkenalkan atau menyebarluaskan suatu produk ke masyarakat untuk membantu mencapai tujuan penjualan (Swastha \& Handoko, 2000; Tjiptono, 2008; Budiarto, 2011). Publisitas dapat diukur dengan beberapa indikator, yaitu (1) pemberitaan produk yang actual, (2) penyelenggaraan special event, dan (3) keterlibatan dalam sponsor. Publisitas juga mempengaruhi keputusan pembelian, dan akan berdampak terhadap penjualan suatu produk. Chandra (2005) menyatakan bahwa publisitas memberikan keyakinan tertentu bagi konsumen untuk melakukan pembelian Beberapa hasil studi juga menunjukkan bahwa bublisitas berpengaruh terhadap keputusan pembelian (Togas, Sepang \& Wenas, 2014). Publisitas berpengaruh terhadap proses keputusan pembelian (Sandy, Arifin \& Yaningwati, 2014), dan berpengaruh terhadap loyalitas konsumen (Sudarwati, Kustiyah \& Tsani, 2017).

Sales promotion (promosi penjualan) juga penting dalam promosi suatu produk. Promosi penjualan adalah 
bentuk persuasi langsung melalui penggunaan berbagai insentif yang dapat diatur untuk merangsang pembelian produk dan meningkatkan jumlah barang yang akan dibeli pelanggan (Tjiptono, 2008). Hasil studi menunjukkan bahwa promosi penjualan berpengaruh terhadap proses dan keputusan pembelian (Sandy, Arifin \& Yaningwati, 2014; Natalia \& Mulyanan, 2014; Lontoh, 2016; Yan, Repi \& Lumanauw, 2018). Beberapa indikator untuk mengukur promosi penjualan, yaitu (1) memiliki daya tarik, (2) membangkitkan keinginan berbelanja, (3) mendorong untuk melakukan pembelian, (4) memberikan perhatian (Sutisna 20013).

Direct marketing (penjualan langsung) adalah komunikasi langsung antara penjual dan calon pembeli yang membentuk pe-mahaman pembeli terhadap produk, sehingga konsumen akan mencoba dan membelinya (Kotler \& Armstrong, 2008). Hasil studi penunjukkan bahwa penjualan langsung berpengaruh terhadap proses keputusan pembelian (Sandy, Arifin \& Yaningwati, 2014; Lontoh, 2016). Indikator penjualan langsung, yaitu (1) acuan pada konsumen, meliputi pesan dapat disiapkan untuk menarik konsumen yang dituju, (2) Up-to-date, meliputi pesan dapat disiapkan dengan cepat, dan (3) interaktif, meliputi pesan yang dapat diubah tergantung pada repon konsumen (Chandra, 2016).

Perilaku konsumen adalah kegiatan individu yang secara langsung mem-peroleh, dan mempergunakan barang dan jasa, termasuk didalamnya proses pengambilan keputusan (Swastha \& Handoko, 2000; Lamb, 2001; Setiadi, 2003). Perilaku konsumen adalah kegiatan seseoran dalam pencarian, pembelian, penggunaan, dan pengevaluasian suatu produk dan jasa yang dapat memuaskan kebutuhannya (Schiffman dan Kanuk, 2004; Kismono, 2011. Sedangkan faktor-faktor yang dapat memengaruhi perilaku konsumen, antara lain referensi, motivasi, persepsi, keyakinan dan sikap (Kotler \& Armstrong, 2001). Perilaku konsumen dalam pembelian suatu produk dapat diukur dengan beberapa indikator, yaitu (1) kesediaan konsumen untuk membeli produk tinggi, (2) ketersediaan konsumen membeli sebuah produk meskipun harganya mahal, (3) ketersediaan konsumen untuk memilih satu produk tertentu dibandingkan dengan produk yang lain, (4) adanya keterkaitan secara terus menerus antara konsumen dengan produk, 5) adanya pengaruh yang ditimbulkan dari norma kelompok untuk konsumen dalam melakukan pembelian (Suki, 2013; Suryani, 2008).

Pengambilan keputusan pembelian merupakan proses penilaian dengan menggunakan pengalaman yang ada dalam pemilihan terhadap berbagai produk sesuai dengan kepentingan. Walker (1997) menyatakan bahwa pengambilan keputusan pembelian adalah suatu pendekatan penyelesaian masalah pada kegiatan manusia membeli suatu produk guna memenuhi keinginan dan kebutuhannya. Kotler (2002) menyatakan bahwa keputusan adalah suatu proses membuat keputusan membeli, dan perilaku setelah membeli yang dilalui oleh konsumen. Pengambilan keputusan dipengaruhi oleh beberapa faktor, diantaranya sampel, dan kualitas produk (Schiffman dan Kanuk, 2000). Sampel suatu produk lebih efektif untuk mendorong terjadinya keputusan pembelian responden (Nilam \& Nurzulia, 2014). Ada pengaruh kualitas produk terhadap keputusan dan loyalitas pembelian (Rezki, 2014). Priyanto (2014) menyebutkan empat faktor utama yang dapat mempengaruhi keputusan pembelian, diantaranya faktor budaya (budaya, sub-budaya, kelas sosial), faktor sosial (kelompok acuan, keluarga, peran dan status), faktor pribadi (usia, pekerjaan dan lingkungan ekonomi, gaya hidup, 
Jurnal Ilmiah Ekonomi dan Bísnis

Vol. 16. No.1, Maret 2019: 35-45

EISSN : $2442-9813$

ISSN : $1829-9822$

kepribadian) dan faktor psikologis (motivasi, persepsi, pembelajaran). Sehingga keputusan pembelian dapat diukur melalui empat indikator, yaitu (1) kebutuhan dan keinginan akan suatu produk, (2) keinginan mencoba, (3) kemantapan akan kualitas suatu produk, dan (4) keputusan pembelian ulang (Chandra, 2016).

Kerangka berpikir dalam menggambarkan pengaruh bauran promosi terhadap prilaku konsumen dalam pengambilan keputusan pembelian suatu produk seperti gambar 1 berikut.

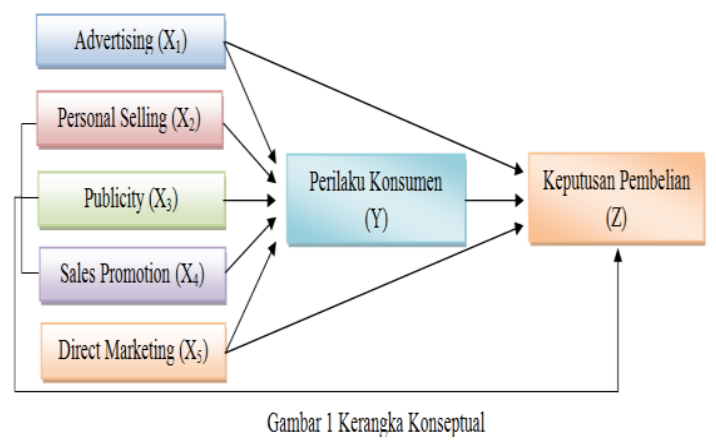

\section{METODE PENELITIAN}

Jenis penelitian adalah eksplansiasosiatif, yaitu penjelasan pengaruh yang saling berhubungan langsung maupun tidak langsung diantara variabel penelitian.

Instrumen penelitian menggunakan angket yang meliputi lima bauran promosi (X). Pertama advertising (X1), meliputi indikator menarik perhatian (X11), memiliki daya tarik (X12), membangkitkan keininginan berbelanja (X13), dan mendorong untuk melakukan pembelian (X14). Kedua, personal selling (X2) meliputi indikator kemampuan bertatap muka dengan baik untuk menawarkan produknya (X21), kemampuan berinteraksi dengan baik kepada konsumen (X22), kemampuan membangun hubungan yang harmonis kepada konsumen (X23), mampu membuat konsumen respon terhadap produk yang ditawarkan (X24), dan mampu menanggapi keluhan konsumen dengan baik (X25). Ketiga, publicity (X3) meliputi indikator pemberitaan produk secara atual (X31), penyelenggaraan spesial even (X32), dan keterlibatan sponsor (X33). Keempat, sales promotion (X4) yaitu kemampuan memiliki daya tarik (X41), membangkitkan keinginan berbelanja (X42), mendorong untuk melakukan pembelian (X43), dan memberikan perhatian (X44). Kelima, direct marketing (X5) meliputi indikator pesanan sesuai dengan keinginan (X51), pesanan dapat diperoleh dengan cepat (X52), dan pesanan dapat diubah sesuai kebutuhan (X53). Perilaku konsumen (Y), yaitu (1) bersedia membeli produk tinggi, (2) bersedia membeli suatu produk meskipun harganya mahal, (3) memilih satu produk tertentu dibandingkan dengan produk yang lain, (4) adanya keterkaitan kesinambungan antara konsumen dengan produk, (5) adanya pengaruh yang ditimbulkan dari norma kelompok untuk konsumen dalam melakukan pembelian. Keputusan pembelian (Z). disebabkan beberapa indikator, yaitu (1) kebutuhan yang harus dipenuhi, (2) faktor keinginan, (3) mudah mencari informasi mengenai produk, (4) kepuasan terhadap produk, dan (5) kinerja produk sesuai dengan yang diharapkan. Produk yang dipertanyakan adalah handphone.

Untuk mengukur kelima bauran dan indikator promosi terhadap prilaku konsumen dalam keputusuan pembelian produk diberikan beberapa pernyataan yang menggunakan lima pilihan jawaban dengan nilai dan skala Likert, yaitu $5=$ sangat setuju, $4=$ setuju, $3=$ ragu ragu, $2=$ tidak setuju, dan $1=$ sangat tidak setuju. Untuk menjamin validitas tes dilakukan dengan expert judgment, dan uji reliabilitas menggunakan rumus Cronbach's Alpha (Allen \&Yenn,1979), yaitu $\quad \alpha=\left[\frac{N}{N-1}\right]\left[\frac{\sigma_{x-\sum_{i=1}^{2} \sigma_{y_{i}}^{2}}^{2}}{\sigma_{x}^{2}}\right] . \quad$ Kriteria instrument, reliabel apabila $\alpha \geq 0.754$ dengan taraf signifikansi $\alpha=0.05$. 
Berdasarkan uji reliabilitas dengan bantuan SPSS versi 19, menunjukkan bahwa instrumen penelitian adalah reliabel dengan nilai Cronbach's Alpha sebesar 0.803, dan untuk indikator X1, X2, X3, X4, X5, Y, dan Z, dengan nilai Cronbach's Alpha berturut-turut sebesar $0.781,0.778$, $0.799,0.557,0.777,0.785$, dan 0.764 .

Populasi penelitian ini adalah semua mahasiswa baru STIE LMII Medan tahun akademik 2018-2019 sebanyak 146 orang. Teknik sampling menggunakan rumus Slovin (Ryan, 2013) dengan tingkat kepercayaan 95\% $(\alpha=0,05)$, yaitu $n=\frac{N}{1+N \alpha^{2}}$, dimana $\mathrm{N}$ adalah ukuran populasi, $\mathrm{n}$ adalah ukuran sampel, dan $\alpha$ adalah tingkat kepercayaan. Berdasarkan perhitungan diperoleh jumlah sampel, $n=$ $\frac{146}{1+146(0.05)^{2}}=105$.

Analisis data menggunakan model persamaan structural (Sugiyono, 2011). Analisis dilakukan tiga tahap, yaitu (1) menguji korelasi variabel utama, (2) menguji signifikansi terhadap tingkat kepercayaan. Apabila Sig. S 0.05, maka variabel memberikan kontribusi yang berarti, dan (3) menentukan pengaruh terbaik.

\section{HASIL DAN PEMBAHASAN}

Analisis data dengan bantuan software SPSS Versi 19, diperoleh besaran korelasi diantara dua variable dengan uji $r$, keberartian koefisien regresi dengan uji $t$ dengan $\alpha=0.05$, dan nilai $\beta$ (beta) untuk mengetahui besar koefisien jalur diantara dua variabel. Proses analisis dilakukan dengan tiga tahap secara berulang hingga diperoleh jalur terbaik.

Untuk menjawab pertanya penelitian yang pertama, maka dilakukan tahapan sebagai berikut. Tahap pertama, menguji korelasi variabel utama. Ringkasan analisis korelasi variabel utama seperti dalam Tabel 1 menunjukkan bahwa semua variable utama berkorelasi secara signifikan terhadap Z, akan tetapi hanya variabel $\mathrm{X} 3$, dan $\mathrm{X} 4$ yang berkorelasi secara signifikan terhadap $\mathrm{Y}$. Tabel 1. Korelasi variable utama

\begin{tabular}{|c|c|c|c|c|c|c|c|}
\hline \multicolumn{8}{|c|}{ Correlations } \\
\hline Var. & $\mathrm{X} 1$ & $\mathrm{X} 2$ & $\mathrm{X} 3$ & $\mathrm{X} 4$ & $x 5$ & $Y$ & Z \\
\hline $\mathrm{X} 1$ & 1 & $.215^{\circ}$ & $.246^{\circ}$ & $.372^{* *}$ & .126 & .152 & $.301^{* *}$ \\
\hline $\mathrm{X} 2$ & $.215^{\circ}$ & 1 & -.047 & $.320^{\circ *}$ & $.245^{\circ}$ & .128 & $.218^{\circ}$ \\
\hline $\mathrm{X3}$ & $.246^{\circ}$ & -.047 & 1 & $.214^{*}$ & $.236^{\circ}$ & $.339^{* *}$ & $.241^{\circ}$ \\
\hline $\mathrm{X} 4$ & $.372^{* *}$ & $.320^{\circ *}$ & $.214^{\circ}$ & 1 & $.255^{\circ *}$ & $.356^{* *}$ & $.416^{* *}$ \\
\hline $\mathrm{X} 5$ & .126 & $.245^{\circ}$ & $.236^{\circ}$ & $.255^{* *}$ & 1 & .090 & $.336^{* *}$ \\
\hline$Y$ & .152 & .128 & $.339^{\circ *}$ & $.356^{\circ *}$ & .090 & 1 & $.312^{* *}$ \\
\hline Z & $.301^{* *}$ & $.218^{\circ}$ & $.241^{\circ}$ & $.416^{* *}$ & $.336^{\circ *}$ & $.312^{* *}$ & 1 \\
\hline
\end{tabular}

Tahap kedua, Uji signifikansi terhadap taraf kepercayaan. Ringkasan dalam Tabel 2 menunjukkan bahwa nilai $t, \quad$ Sig $\leq 0.05$, berarti hanya variable $\mathrm{X} 4$, X5, dan $\mathrm{Y}$ yang berkontribusi ke variable $\mathrm{Z}$. Tabel 3 menunjukkan bahwa hanya variable $\mathrm{X} 3, \mathrm{X} 4$, dan $\mathrm{Y}$ yang mempunyai kontribusi ke variable $\mathrm{Z}$, dan Tabel 4 menunjukkan bahwa hanya variable X4 dan X5 yang berkontribusi ke variable $\mathrm{Z}$

Tabel 2. Koefisien regresi variabel $X 1$, $\mathrm{X} 2, \mathrm{X} 3, \mathrm{X} 4, \mathrm{X} 5$, Y terhadap Z

$$
\text { Coefficients }^{\mathrm{a}}
$$

\begin{tabular}{|c|r|r|r|r|r|}
\hline \multirow{2}{*}{ Model } & \multicolumn{2}{|c|}{$\begin{array}{c}\text { Unstandardized } \\
\text { Coefficients }\end{array}$} & $\begin{array}{r}\text { Standardized } \\
\text { Coefficients }\end{array}$ & & \\
\cline { 2 - 4 } & \multicolumn{1}{|c|}{$\mathrm{B}$} & Std. Error & \multicolumn{1}{c|}{ Beta } & \multicolumn{1}{c|}{$\mathrm{t}$} & \multicolumn{1}{c|}{ Sig. } \\
\hline 1 (Constant) & \multicolumn{1}{|c}{.154} & .552 & & 2.090 & .039 \\
X1 & .127 & .079 & .149 & 1.597 & .113 \\
X2 & .028 & .094 & .028 & .296 & .768 \\
X3 & .031 & .092 & .033 & .337 & .737 \\
X4 & .189 & .089 & .202 & 2.116 & .037 \\
X5 & .188 & .075 & .232 & 2.492 & .014 \\
Y & .205 & .086 & .220 & 2.388 & .019 \\
\hline
\end{tabular}

Tabel 3. Koefisien regresi variabel $X 1$, X2, X3,X4, X5 terhadap Y Coefficients $^{\mathrm{a}}$

\begin{tabular}{|l|r|r|r|r|r|}
\hline \multirow{2}{*}{ Model } & \multicolumn{2}{|c|}{$\begin{array}{c}\text { Unstandardized } \\
\text { Coefficients }\end{array}$} & $\begin{array}{c}\text { Standardized } \\
\text { Coefficients }\end{array}$ & & \multirow{2}{*}{} \\
\cline { 2 - 4 } & \multicolumn{1}{|c|}{ B } & Std. Error & \multicolumn{1}{c|}{ Beta } & \multicolumn{1}{c|}{$\mathrm{t}$} & \multicolumn{1}{c|}{ Sig. } \\
\hline 1 (Constant) & 1.473 & .573 & & 2.571 & .012 \\
X1 & -.037 & .087 & -.042 & -.424 & .673 \\
X2 & .077 & .104 & .073 & .740 & .461 \\
X3 & .297 & .094 & .305 & 3.156 & .002 \\
X4 & .277 & .094 & .302 & 2.944 & .004 \\
X5 & -.060 & .080 & -.072 & -.743 & .459 \\
\hline
\end{tabular}

a. Dependent Variable: $Y$ 
Tabel 4. Koefisien regresi variabel $\mathrm{X} 1, \mathrm{X} 2, \mathrm{X} 3, \mathrm{X} 4, \mathrm{X} 5$ terhadap Z

Coefficients $^{\mathrm{a}}$

\begin{tabular}{|c|r|r|r|r|r|}
\hline \multirow{2}{*}{ Model } & \multicolumn{2}{|c|}{$\begin{array}{c}\text { Unstandardized } \\
\text { Coefficients }\end{array}$} & $\begin{array}{c}\text { Standardized } \\
\text { Coefficients }\end{array}$ & & \\
\cline { 2 - 4 } & \multicolumn{1}{|c|}{ B } & Std. Error & \multicolumn{1}{c|}{ Beta } & \multicolumn{1}{c|}{ t } & \multicolumn{1}{c|}{ Sig. } \\
\hline 1 (Constant) & 1.429 & .536 & & 2.668 & .009 \\
X1 & .116 & .081 & .137 & 1.430 & .156 \\
X2 & .056 & .097 & .055 & .579 & .564 \\
X3 & .096 & .088 & .102 & 1.090 & .278 \\
X4 & .241 & .088 & .272 & 2.748 & .007 \\
X5 & .172 & .075 & .213 & 2.284 & .024 \\
\hline
\end{tabular}

Berdasarkan Tabel 2, Tabel 3 dan Tabel 4, maka jalur terbaik dari variabel $\mathrm{X}$ ke $\mathrm{Z}$ melalui $\mathrm{Y}$ dapat dinyatakan seperti gambar 2 berikut.

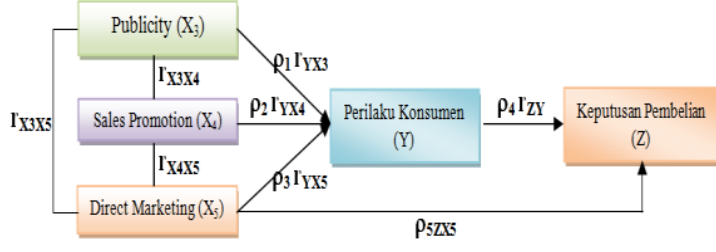

Gambar 2 Jalur Terbaik Bauran Promosi

Tahap ketiga, menentukan pengaruh terbaik dari variable X3, X4 melalui $\mathrm{Y}$ ke $\mathrm{Z}$ dengan cara menghitung besar pengaruh secara proporsional dengan model persamaan struktural sebagai berikut.

1. Pengaruh langsung

a. Pengaruh $\mathrm{X} 3$ ke $\mathrm{Z}$, yaitu : $P_{1}=\rho_{Y 1 X 3} x \rho_{1 Y X 3}+$ $\rho_{3 Z Y} x \rho_{3 Z Y}$

b. Pengaruh $\mathrm{X} 4$ ke $\mathrm{Z}$, yaitu: $P_{2}=\rho_{2 Y X 4} x \rho_{2 Y X 4}+$ $\rho_{3 Z Y} x \rho_{3 Z Y}$

c. Pengaruh $X 5$ ke $Z$, yaitu: $P_{3}=\rho_{5 Z x 5}$

2. Pengaruh korelasional

a. Pengaruh $X 3$ ke $Z$, yaitu: $P_{4}=\rho_{1 Y X 3} x \rho_{1 Y X 3}+$ $\rho_{1 Y X 3} x r_{X 3 X 4} x \rho_{1 Y X 3}+$ $\rho_{3 Z Y} x \rho_{3 Z Y}$

b. Pengaruh $\mathrm{X} 4$ ke $\mathrm{Z}$, yaitu: $P_{5}=\rho_{2 Y X 4} x \rho_{2 Y X 4}+$ $\rho_{2 Y X 4} x r_{X 4 X 3} x \rho_{2 Y X 4}+$ $\rho_{3 Y X 4} x \rho_{3 Y X 4}$
Setelah disubsitusi nilai korelasi dalam Tabel 1, dan koefisien jalur dalam Tabel 2, Tabel 3, dan Tabel 4 ke model persamaan struktural, maka diperoleh hasil dengan besar persentase kontribusi, yaitu $P_{1}=14,14 \%, P_{2}=13,94 \%, P_{3}=4,80 \%$, $P_{4}=18,29 \%, \quad P_{5}=18,12 \%$. Hal itu menunjuk-kan bahwa faktor dominan pengaruh bauran promosi terhadap prilaku konsumen dalam pengambilan keputusan pembelian produk handpone dipengaruhi oleh (1) faktor publicity dan sales promotion $(18,29 \%)$, (2) faktor sales promotion dan publicity $(18,12 \%)$, (3) pengaruh langsung faktor publicity $(14,14 \%)$, (4) pengaruh langsung faktor sales promosion (13,94\%), dan (5) pengaruh langsung faktor direct marketing $(4,80 \%)$

Menjawab pertanyaan penelitian kedua, maka dilakukan tahapan sebagai berikut. Tahap pertama, menguji korelasi variabel indikator. Ringkasan analisis korelasi variabel indikator seperti dalam Tabel 5 menunjukkan bahwa beberapa variable indikator X3 dan X4 yaitu X31, dan X41, X43, X44 berkorelasi secara sangat signifikan terhadap Y.

Tabel 5 Korelasi variabel indikator X3 dan X4 terhadap Y

Correlations

\begin{tabular}{|c|c|c|c|c|c|c|c|c|}
\hline & X31 & $\times 32$ & $\times 33$ & X41 & $X 42$ & $\times 43$ & X44 & Y \\
\hline X31 & 1 & $.313^{* *}$ & .040 & .100 & .031 & .162 & 156 & $.262^{\circ}$ \\
\hline$\times 32$ & $.313^{*}$ & 1 & $.203^{\circ}$ & .088. & .069 & .030 & 184. & 144. \\
\hline$X 33$ & .040 & $.203^{\circ}$ & 1 & .097 & .162 & .044 & .125 & .072 \\
\hline$X 41$ & .100 & .088 & .097 & 1 & $.447^{\prime \prime}$ & $.269^{\circ}$ & $.457^{\circ \prime}$ & $.260^{* *}$ \\
\hline$x 42$ & .031 & .069 & .162 & $.447^{\circ *}$ & 1 & $.361^{\prime \prime}$ & $.386^{\circ \prime}$ & $.361^{*}$ \\
\hline$\times 43$ & .162 & .030 & .044 & $.269^{\circ}$ & $.361^{\circ}$ & 1 & $.333^{\circ *}$ & 181 \\
\hline$x 44$ & .156 & .184 & .125. & $.457^{\circ "}$ & $.386^{\circ \prime}$ & $.333^{\circ}$ & 1 & $.410^{\circ *}$ \\
\hline$Y$ & $262^{*}$ & .144 & .072 & $.260^{\circ}$ & $.361^{* *}$ & .181 & $.410^{\circ}$ & 1 \\
\hline
\end{tabular}

Tahap kedua, Uji signifikansi terhadap tingkat kepercayaan. Ringkasan koefisien regresi dalam Tabel 6 menunjukkan bahwa hanya variabel X31, X42 dan X44 yang secara signifikan memberikan kontribusi terhadap variabel Y. 
Tabel 6. Koefisien regresi indikator variabel $\mathrm{X} 3$ dan $\mathrm{X} 4$ terhadap $\mathrm{Y}$ Coefficients $^{a}$

\begin{tabular}{|l|r|r|r|r|r|}
\hline \multirow{2}{*}{ Model } & \multicolumn{2}{|c|}{$\begin{array}{c}\text { Unstandardized } \\
\text { Coefficients }\end{array}$} & $\begin{array}{c}\text { Standardized } \\
\text { Coefficients }\end{array}$ & & \\
\cline { 2 - 4 } & \multicolumn{1}{|c|}{ B } & Std. Error & \multicolumn{1}{|c|}{ Beta } & \multicolumn{1}{c|}{ t } & \multicolumn{1}{c|}{ Sig. } \\
\hline 1 (Constant) & 1.684 & .430 & & 3.922 & .000 \\
X31 & .144 & .063 & .212 & 2.270 & .025 \\
X32 & .007 & .064 & .010 & .105 & .917 \\
X33 & -.010 & .057 & -.015 & -.166 & .868 \\
X41 & .002 & .081 & .002 & .022 & .983 \\
X42 & .179 & .072 & .258 & 2.478 & .015 \\
X43 & -.030 & .067 & -.044 & -.448 & .655 \\
X44 & .198 & .071 & .291 & 2.787 & .006 \\
\hline
\end{tabular}

Tahap ketiga, menentukan jalur terbaik indikator variabel X31, X42, dan $\mathrm{X} 44$ ke $\mathrm{Z}$ melalui $\mathrm{Y}$ dapat dinyatakan seperti gambar 3 berikut.

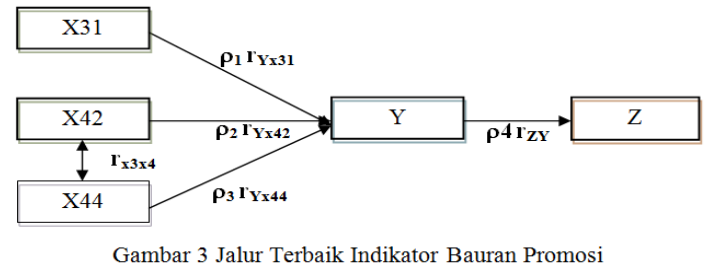

Berdasarkan Gambar 3 dapat dihitung jalur terbaik, yaitu prosentase terbesar dari variable indikator X31, $\mathrm{X} 42$, dan X44 ke Z melalui $\mathrm{Y}$ dengan cara menghitung besar pengaruh secara proporsional dengan model persamaan struktural sebagai berikut.

1. Pengaruh langsung

a. Pengaruh X31 ke Z, yaitu : $P_{1}=\rho_{1 Y X 31} x \rho_{Y X 31}+\rho_{Z Y} x \rho_{Z Y}$

b. Pengaruh $X 42$ ke $Z$, yaitu: $P_{2}=\rho_{2 Y X 4} x \rho_{Y X 4}+\rho_{Z Y} x \rho_{Z Y}$

c. Pengaruh $X 44$ ke $Z$, yaitu: $P_{3}=\rho_{3 Y X 44} x \rho_{Y X 44}+\rho_{Z Y} x \rho_{Z Y}$

2. Pengaruh korelasional

a. Pengaruh X42 ke Z, yaitu: $P_{4}=\rho_{2 Y X 42} x \rho_{2 Y X 42}+$ $\rho_{2 Y X 42} x r_{X 42 X 44} x \rho_{2 Y X 42}+$ $\rho_{4 Z Y} x \rho_{4 Z Y} \mathrm{P}$

$P_{5}=$

b. Pengaruh X44 ke Z, yaitu:

$\rho_{3 Y X 44} x \rho_{3 Y X 44}+$

$\rho_{3 Y X 44} x r_{X 4 X 3} x \rho_{3 Y X 44}+\rho_{4 Y Z} x \rho_{4 Y Z}$

Setelah disubsitusi nilai korelasi dalam Tabel 1, Tabel 5 dan koefisien regresi dalam Tabel 6 ke model persamaan struktural, maka diperoleh hasil kontribusi dalam besaran persentase, yaitu $P_{1}=9,29, P_{2}=11,46 \%, P_{3}=13,27 \%$, $P_{4}=11,03 \%, \quad P_{5}=21,54 \%$ Hal itu menunjukkan bahwa faktor dominan pengaruh indikator bauran promosi terhadap prilaku konsumen dalam pengambilan keputusan pembelian handphone dipengaruhi oleh (1) faktor sales promotion yang memberikan perhatian dan mendorong untuk melakukan pembelian (21,54\%), (2) faktor sales promotion yang memberikan perhatian konsumen $(13,27 \%)$, (3) faktor sales promotion yang mem-bangkitkan keinginan belanja secara langsung mempengaruhi prilaku konsumen untuk keputusan pembelian $(11,46 \%)$, (4) faktor sales promotion yang membangkit-kan keinginan belanja mempengaruhi prilaku konsumen untuk keputusan pembelian (11,03\%), dan (5) faktor publicity dalam pemberitaan produk secara actual mempengaruhi prilaku konsumen terhadap keputusan pembelian $(9,29 \%)$.

\section{KESIMPULAN DAN SARAN}

Pemasaran bagian penting dalam mendistribusikan suatu produk kepada konsumen. Promosi salah satu unsur dalam strategi pemasaran yang dapat mempengaruhi peningkatan volume penjualan. Bauran promosi terdiri atas lima unsur, yaitu advertising, personal selling, publicity, sales promotion dan direct marketing. Telah dilakukan penelitian untuk mengetahui faktor mana yang paling dominan untuk mempengaru-hi perilaku konsumen terhadap keputusan pembelian suatu produk. Berdasarkan hasil analisis data disimpulkan bahwa secara simultan, yaitu publicity dan sales promotion, dan secara parsial, yaitu publicity, sales promosion, dan direct marketing merupakan faktor dominan dari bauran promosi yang mempengaruhi prilaku konsumen dalam pengambilan keputusan pembelian handpone.

Dilihat dari indikator bauran promosi, faktor sales promotion dan 


\section{Jurnal Ilmiah Ekonomi dan Bísnis}

Vol. 16. No.1, Maret 2019: 35-45

EISSN : $2442-9813$

ISSN : $1829-9822$

publicity adalah faktor dominan yang mempengaru-hi prilaku konsumen dalam pengambilan keputusan pembelian produk handpone. Hal tersebut disebabkan sales promotion dapat memberikan perhatian konsumen terhadap produk, mendorong dan membangkitkan keinginan calon konsumen untuk melaku-kan pembelian. Faktor publicity, pemberita-an produk secara aktual mempengaruhi prilaku konsumen terhadap keputusan pembelian.

Untuk keberhasilan pemasaran suatu produk maka perlu diperhatikan unsur penting dalam kegiatan promosi. Tanpa mengabaikan unsur-unsur bauran promosi, sales promotion adalah satu unsur yang penting dan paling baik digunakan dalam pemasaran suatu produk. Karena sales promotion dapat memberikan perhatian konsumen terhadap produk, mendorong dan membangkitkan keinginan calon konsumen untuk melakukan pembelian.

\section{DAFTAR PUSTAKA}

Allen, M. J., \& Yen, W. M. 1979. Introduction to Measurement Theory. Monterey: Brooks /Cole Publishing company

Alma, B. 2005. Manajemen Pemasaran dan Pemasaran Jasa. Cetakan ke-7. Bandung: Alfabeta

Babin.2011.Menjelajahi Riset Pemasaran. Jakarta: Penerbit Salemba Empat

Budiarto, S. 2011. Pemasaran Industri. Yogyakarta: Andi

Chandra, E. 2016. Hubungan Direct Marketing dan Personal Selling Terhadap Keputusan Pembelian Pie Elis. PERFORMA: Jurnal Managemen dan Strat-Up Bisnis, 1(4), 414-423.
Chandra, G. 2005. Strategi dan Program Pemasaran. Yogyakarta: ANDI

Dellamita, M. F, dkk, 2014. Penerapan Personal Selling (Penjualan Pribadi) untuk Meningkatkan Penjualan. Jurnal Administrasi Bisnis. $\quad 9 \quad$ (2), 1-6. http://download.portalgaruda.org/a rticle.php? article $=189953 \& \mathrm{val}=64$ $68 \&$ title=penerapan $\% 20$ personal $\%$ 20 selling\%20\%28penjualan\%20pri bad

Fortunisa, A., \& Agassi, A. A. 2012. Pesan Iklan Televisi dan Personal Selling: Alat Promosi untuk Peningkatan Keputusan Pembelian. Jurnal Elektronik, 2 (2). 377-385. http://journal.bakrie.ac.id/index.ph p/Journal_Communication_spectru $\mathrm{m} /$ article/view/283/247

Gitosudarmo, I. 2000. Manajemen Pemasaran. Yogyakarta: BPFE

Hasan, A. (2008). Marketing. Yogyakarta: MedPress

Hermawan, A. 2012. Komunikasi Pemasaran. Jakarta: Erlangga

Kismono, G. 2011. Bisnis Pengantar. Edisi Kedua. Yogyakarta: BPFE

Kotler, P. 2002. Manajemen Pemasaran. Jakarta: PT. Prehanlindo

Kotler, P. 2005. Manajemen Pemasaran, Jilid 1. Klaten: PT. Intan Sejati.

Kotler, P. 2007. Manajemen Pemasaran. Edisi 12 jilid 1. Jakarta: PT. Macanan Jaya Cemerlang.

Kotler, P., \& Armstrong, G. 2001. Principle of Marketing. $8^{\text {th }}$ Edition. New Jersey: Prentice Hall. 
Kotler, P., \& Keller, K.L. 2012. Marketing Management, Fourteen Edition. England: Pearson Education Limited

Kusmayani, D. K. Y., Anjuman, Z., dan Indrayani, L. 2014. Pengaruh Personal Selling terhadap Keputusan Pembelian Produk Oriflame di Queneno Group Singaraja Tahun 2014. Jurnal Elektronik, $\quad 4(1) .1-11$. http://ejournal.undiksha.ac.id/ind ex.php/JJPE/ article/view /4063/3207

Lamb, C. W. 2001. Pemasaran. Jakarta: Salemba Empat

Lontoh, M. N. 2016. Analisis Pengaruh Bauran Promosi Terhadap Keputusan Pembelian Mobil Toyota pada PT Hasjrat Abadi Manado Cabang Tendean. Jurnal Berkala Ilmiah, 16(01),515-525. https://ejournal.unsrat.ac.id/index .php/jbie/article/

Mariana. 2015. Pengaruh Kualitas Produk dan Harga Terhadap Keputusan Pembelian Produk pada Industri Ukm Amplang Ud. Sinar Rejeki di Samarinda. Jurnal Administrasi Bisnis, 3(2), 388402.

http://ejournal.adbisnis.fisipunmu l.ac.id/ jurnal \% 20Mariana\% 20(05-19-15-03-34-14).pdf.

Moriarty., Sandra., Mitchell, N., \& William Wells, W. 2009. Advertising. Diterjemahkan oleh: Tribowo B.S. 2011. Edisi 8. Jakarta: Kencana.

Natalia, P., \& Mulyana, M. 2014. Pengaruh Periklanan Dan Promosi Penjualan Terhadap Keputusan Pembelian. Jurnal
Ilmiah Manajemen Kesatuan, 2 (2), 119-128. file://C: /Users/acer/Downloads/13IMKES2014Vol2No2PriccilaNatal iadanMumuh Mulyana.pdf

Nilam, N. D., \& Nuzulia. 2014. Efektivitas Personal Selling dan Sales Promotion dengan Sampel Produk Trehadap Keputusan Pembelian Konsumen. Journal of Social and Industrial Psychology, 3 (1), 41-47

Panjaitan, T. H. 2016. Pengaruh Persona; Selling Terhadap Pembelian (Studi Kasus PT Millenium Pharmacon International Tbk Cabang Bandung). e-Proceeding of Applied Science, 2 (2), 448-457.

Priyanto, R. E. 2014. Pengaruh Personal Selling dan Kualitas Produk Terhadap Keputusan Pembelian. Jurnal Ilmiah Manajemen Kesatuan, 2 (1), 69-78. http://jurnal. Stiekesatuan .ac.id/index.php/jimk/article/view/ $412 / 440$

Qolbi, U. S., Fauzi, A., \& Sunarti. 2014. Pengaruh Iklan Terhadap Sikap Konsumen (Survei pada Pengunjung yang Pernah Bermain Game Pro Evolution Soccer di Flux Capital of Entertainment Kecamatan Blimbing Kota Malang). Jurnal Administrasi Bisnis (JAB), 10 (1), 1-8. http://download.portalgaruda.org/a rticle.php?article $=190017 \&$ val $=64$ 68 title $=$ PENGARUH\%20IKLAN\%2 OTERHADAP\%20SIKAP\%20KO NSUMEN\% 20

Ryan, T. 2013. Sample Size Determination and Power. New York: John Wiley and Sons 
Jurnal Ilmiah Ekonomi dan Bísnís

Vol. 16. No.1, Maret 2019: 35-45

EISSN : $2442-9813$

Rezki, R. 2014. Pengaruh Kualitas Produk, Harga, Lokasi Dan Promosi Terhadap Keputusan Pembelian Ruko Pada Cv. Sinar Jaya Global Steel Padang. Jurnal Manajemen dan Kewirausahaan, 6(5), 1-21. http://journal.unitaspdg.ac.id/dow nlot filemh.phpfile $=$ JurnalRahmadRezki

Sandy, F., Arifin Z., \& Yaningwati, F. 2014. Pengaruh Bauran Promosi Terhadap Keputusan Pembelian (Survei pada Mahasiswa Jurusan Bisnis Angkatan 2010-2012 Fakultas Ilmu Adminsitrasi Pengguna Indosat di Universitas Brawijaya). Jurnal Administrasi Bisnis (JAB), 9 (2), 1-10. http://download.portalgaruda.org/ article.php?

Setiadi, N. J. 2003. Perilaku Konsumen: Konsep dan Implikasinya untuk Strategi dan Penelitian Pemasaran. Jakarta: Prenada Media.

Schiffman, L.G., \& Kanuk, L.L. 2000, Consumer Behavior, $7^{\text {th }}$ Ed, New Jersey: Prentice Hall.

Schiffman, L.G., \& Kanuk, L. L. 2004. Consumer Behaviour, Fifth Editions. New Jersey: PrenticeHall Inc.

Sivanesan, R. 2014. Impact of Brand Image and Advertisement on Consumer Buying BehaviorComparative Study on Rural and Urban Consumers". International Journal of Research in Management \& Business Studies. 1(2),73-80.

http://ijrmbs.com/vol1 issue 2/1/ r_sivanesan.pdf
Sudarwati., Kustiyah, E., \& Tsani, F. A. 2017. Pengaruh Periklanan, Personal Selling, Publisitas dan Promosi Penjualan Terhadap Loyalitas Konsumen (Studi Kasus di PT. Batik Semar Surakarta). Jurnal Manajemen Bisnis Indonesia, 4 (3), 360-372. file://C:/Users/acer/Downloads/12 9-Article\%20Text-263-1-1020180623.pdf

Sugiyono. 2011. Statistika untuk Penelitian. Bandung: Alfabeta

Suki, N. M. 2013. Green Awareness Effects on Consumers Purchasing Decision: Some Insights From Malaysia. IJAPS, 9 (2), 1-10

Sunyoto, D. 2013. Perilaku Konsumen. Yogyakarta: CAPS

Surjadi, D. 2012. Pengaruh Iklan Terhadap Prilaku Pembelian Konsumen The dalam Keluarga. Jurnal Agro Ekonomi, 20(2),92107.https://dx.doi.org/10.210 82 /jae. v20n2.2002.92-107

Suryani, T. (2008). Perilaku Konsumen: Implikasi pada Strategi Pemasaran. Yogyakarta: Graha Ilmu

Sutisna. 2003. Perilaku Konsumen \& Komunikasi Pemasaran. Bandung: Remaja Rosdakarya

Stanton., William, J. 1991. Prinsip Pemasaran, Edisi Ketujuh, Jilid 1. Jakarta: Erlangga.

Swastha, B., \& Handoko, T.H. 2000. Manajemen Pemasaran (Analisis Perilaku Konsumen), Edisi ke 2. Yogyakarta: Liberty. 
Swastha., \& Irawan. 2005. Manajemen

Pemasaran Modern, Yogyakarta: Liberty.

Tjiptono, F. 2008. Manajemen Pemasaran. Yogyakarta: Andi Ofset.

Togas, N. M.N., Sepang, J. L., \& Wenas, R.S. (2014). Periklanan, Penjualan Pribadi, Promosi Penjualan, dan Publisitas Terhadap Keputusan Pembelian Pada Penerbit Andi Cabang Menado. Jurnal EMBA, 2 (4), 578-588.

http://download.portalgaruda.org/ article.php? article $=292004$

Yan, R. G.P.S, Repi, A., \& Lumanauw, B. 2018. Pengaruh Promosi Penjualan dan Lokasi Terhadap Proses Keputusan Pembelian Kenderaan Bermotor di PT Tridjaya Mulia Sukses Manado. Jurnal EMBA, 6 (1), 101110.https://ejournal.unsrat.ac.id/ index .php/emba/article/viewFile/18831 / 18380

Yudhiartika, D., \& Haryanto, J.O. 2012. Pengaruh Personal Selling, Display, Promosi Penjualan Terhadap Kesadaran Merek dan Intensi Membeli pada Produk Kecantikan Pond's. Jurnal Elektronik, 17 (2),99-225. http://ojs.unud.ac.id/index.php/bs e/ article/ download/2187/1386

Yuniyanto, H. R., \& Sirine, H. 2018 Pengaruh Iklan terhadap Minat Beli Pengguna Youtube dengan Brand Recognition sebagai Variabel Inter-vening. Jurnal Bisnis dan Manajemen, 8 (1), 2128. http://journal. uinjkt.ac.id/
index.php/esensi/article/viewFile/ 5885/pdf

Walker, B. L. 1997. Manajemen Pemasa ran, Suatu Pendekatan Strategis dengan Orientasi Global. Jilid 2. Jakarta: Erlangga.

Wariki, G.H., Mananeke, L., \& Tawas, H. 2015. Pengaruh Bauran Promosi, Persepsi Harga dan Lokasi Terhadap Keputusan Pembelian dan Kepuasan Konsumen pada Perumahan Tamansari Metropolitan Manado. Jurnal EMBA, 3 (2), 1073-1085. http://download. Portal garuda.org/article.php?article $=377$ $503 \&$ val $=1025 \&$ title $=$ PENGARU H\%20BAURAN\%20PROMOSI 